\title{
Synthesis and crystal structure of trichromium metal string complex
}

\author{
Hui Li ${ }^{\text {a,b,c }}$, Gene-Hsiang Lee ${ }^{\mathrm{a}}$, Shie-Ming Peng ${ }^{\mathrm{a}, \mathrm{c}, *}$ \\ ${ }^{a}$ Department of Chemistry, National Taiwan University, Taipei 106, Taiwan, ROC \\ ${ }^{\mathrm{b}}$ Department of Chemistry, College of Science, Beijing Institute of Technology, Beijing 100081, People's Republic of China \\ ${ }^{\mathrm{c}}$ Institute of Chemistry, Academia Sinica, Taipei 115, Taiwan, ROC
}

Received 15 May 2004; revised 8 July 2004; accepted 14 July 2004

Available online 23 September 2004

\begin{abstract}
The synthesis, crystal structures and molecular packing of the three trichromium metal string complexes $\left[\mathrm{Cr}_{3}(\mathrm{dpa})_{4} \mathrm{Cl}\left(\mathrm{OC}_{2} \mathrm{H}_{5}\right)\right] \mathrm{OH} \cdot \mathrm{C}_{2}$ -

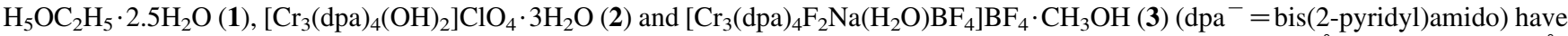
been studied. The crystal structure data for 1 : $\mathrm{C}_{46} \mathrm{H}_{54} \mathrm{ClCr}_{3} \mathrm{~N}_{12} \mathrm{O}_{5.5}$, monoclinic, $P 2{ }_{1} / c, a=19.9998(4) \AA, \quad b=15.9756(3) \AA$, $c=16.9943(3) \AA, \beta=114.0548(8)^{\circ}, Z=4, R_{1}=0.0791, w R_{2}=0.1927$; for $2: \mathrm{C}_{40} \mathrm{H}_{40} \mathrm{ClCr}_{3} \mathrm{~N}_{12} \mathrm{O}_{9}$, orthogonal, Pna2 ${ }_{1}, a=18.3373(2) \AA$, $b=16.8220(2) \AA, c=14.0268(2) \AA, Z=4, R_{1}=0.0683, w R_{2}=0.1804$; for 3: $\mathrm{C}_{41} \mathrm{H}_{38} \mathrm{~B}_{2} \mathrm{Cr}_{3} \mathrm{~F}_{10} \mathrm{~N}_{12} \mathrm{NaO}_{2}$, monoclinic, $P 2{ }_{1} / n, a=$ 12.3902(1) $\mathrm{A}, b=16.2081(2) \AA, c=23.4119(3) \AA, \beta=98.8725(6)^{\circ}, Z=4, R_{1}=0.0670, w R_{2}=0.1568$. The structure data were collected using graphite monochromated molybdenum $\mathrm{K} \alpha$ radiation and refined using full-matrix least square techniques on $F^{2}$. The magnetic property of complex 1 was carried out on polycrystalline samples with a SQUID magnetometer. The IR, FAB-MS mass spectra of all complexes were also measured. In the three complexes, trichromium metal string complexes can be considered as mini-1D asymmetrically chains since the distance between the two axial ligands is around $1 \mathrm{~nm}$. The types of hydrogen bonding in three complexes are $\mathrm{C}-\mathrm{H} \cdots \mathrm{O}, \mathrm{C}-\mathrm{H} \cdots \mathrm{Cl}, \mathrm{C}-\mathrm{H} \cdots \mathrm{F}$ and $\mathrm{O}-\mathrm{H} \cdots \mathrm{O}$ ). 1 and $\mathbf{2}$ have a one-dimensional double-chain structures. $\mathbf{1}$ is a rare example of three-dimensional novel sandwich structure. In 3, one of the axial ligand, $\mathrm{F}^{-}$acts as a bridge ligand to link the sodium ion to the $\mathrm{Cr}_{3}$ axis with a bond angle of $\mathrm{Cr}(1)-\mathrm{F}(1)-\mathrm{Na}$ in $169.90(13)^{\circ}$. It can be considered as a metal string complex with an extra long axis.
\end{abstract}

(C) 2004 Elsevier B.V. All rights reserved.

Keywords: Hydrogen bonding; Metal string complex; Crystal structure; Chromium; Molecular packing

\section{Introduction}

The weak intermolecular interaction is important in the supramolecular chemistry [1,2] and biochemistry [3]. The hydrogen bonding has attracted more attentions than van der Waals (vdW) interactions, for example, electrostatic, dipole-dipole and dispersion interactions since the hydrogen bond has more interaction energy [4]. Comparison with conventional H-bond interactions, $\mathrm{X}-\mathrm{H} \cdots \mathrm{Y}(\mathrm{X}, \mathrm{Y}=\mathrm{O}, \mathrm{N})$, the non-conventional H-bond, $\mathrm{C}-\mathrm{H} \cdots \mathrm{Z}(\mathrm{Z}=\mathrm{O}, \mathrm{N}, \mathrm{S}, \pi$, Agros...), is very weak. But this kind of intermolecular interaction occurs very frequently and the cooperative

\footnotetext{
* Corresponding author. Address: Department of Chemistry, College of Science, Beijing Institute of Technology, Beijing 100081, People's Republic of China. Tel.: + 886-10-6891-2668; fax: +886-2-2789-8665.

E-mail addresses: lihui@bit.edu.cn (H. Li), smpeng@ntu.edu.tw (S.-M. Peng).
}

effects are important [5]. Recently, the H-bond $(\mathrm{C}-\mathrm{H} \cdots \mathrm{O})$ has been studied by Caminati using the molecular beam Fourier transform microwave and free jet millimeter wave absorption spectroscopies in the dimethyl ether dimer system. The results show that the bonding energy of $\mathrm{C}-\mathrm{H} \cdots \mathrm{O}-\mathrm{C}$ linkage is $1.9 \mathrm{~kJ} / \mathrm{mol}$ which is much smaller than that of normal H-bonds $\mathrm{O}-\mathrm{H} \cdots \mathrm{O}(22 \mathrm{~kJ} / \mathrm{mol})$ [6]. However, the cooperative effect of the three weak $\mathrm{C}-\mathrm{H} \cdots \mathrm{O}-\mathrm{C}$ linkages makes the complex sufficiently stable for its detection with their techniques.

We have studied the trinuclear metal string complex, $\left[\mathrm{Ni}_{3}(\mathrm{dpa})_{4} \mathrm{X}_{2}\right]$ assembled by a Ni-F $\cdots \mathrm{H}-\mathrm{O}$ new pattern of hydrogen bonding [7]. To extend this study, the trinuclear chromium metal string complexes have been chosen, which are more interesting due to their multi-bonding between chromium atoms [8-11]. In the neutral species with a $\mathrm{Cr}_{3}(\mathrm{dpa})_{4}^{2+}$ core, the molecules may be either symmetrical or unsymmetrical according to the axial ligand. They are 
easily oxidized to the $\mathrm{Cr}_{3}(\mathrm{dpa})_{4}^{3+}$ core, in which the molecules are always unsymmetrical because the two $\mathrm{Cr}$ (II) atoms are bonded quadruply and the $\mathrm{Cr}$ (III) atom is far from the inner $\mathrm{Cr}(\mathrm{II})$ atom. Here, we have reported $\left[\mathrm{Cr}_{3}(\mathrm{dpa})_{4} \mathrm{Cl}\left(\mathrm{OC}_{2} \mathrm{H}_{5}\right)\right] \mathrm{OH} \cdot \mathrm{C}_{2} \mathrm{H}_{5} \mathrm{OC}_{2} \mathrm{H}_{5} \cdot 2.5 \mathrm{H}_{2} \mathrm{O}(\mathbf{1}),\left[\mathrm{Cr}_{3}\right.$ (dpa $\left.)_{4}(\mathrm{OH})_{2}\right] \mathrm{ClO}_{4} \cdot 3 \mathrm{H}_{2} \mathrm{O}$ (2) and $\left[\mathrm{Cr}_{3}(\mathrm{dpa})_{4} \mathrm{~F}_{2} \mathrm{Na}\left(\mathrm{H}_{2} \mathrm{O}\right)\right.$ $\left.\mathrm{BF}_{4}\right] \mathrm{BF}_{4} \cdot \mathrm{CH}_{3} \mathrm{OH}(3)$. The synthesis, crystal structure and molecular packing of the three complexes have been studied.

\section{Experimental}

All chemicals are commercially available, and reagent products were used without purification. Solvents were purified and freshly distilled under nitrogen before use. The starting materials, $\mathrm{Cr}_{3}(\mathrm{dpa})_{4} \mathrm{Cl}_{2}$, was synthesized under dry argon using standard Schlenk and glovebox techniques. $\mathrm{CrCl}_{2}(1 \mathrm{~g}, 8.14 \mathrm{mmol})$, Hdpa $(1.857 \mathrm{~g}, 10.85 \mathrm{mmol})$ and naphthalene $(30 \mathrm{~g})$ were placed in an Erlenmejer flask under argon. This mixture was heated at $200{ }^{\circ} \mathrm{C}$ for $3 \mathrm{~h}$ with stirring. A solution of $n$-BuOK $(1.34 \mathrm{~g}, 11.93 \mathrm{mmol})$ in $20 \mathrm{ml} n-\mathrm{BuOH}$ was added dropwise with an injector. Heating was continued until the remaining $n$-butanol was evaporated completely. After the mixture was cooled, $n$-hexane was added to wash out the naphthalene. The product was extracted with $\mathrm{CH}_{2} \mathrm{Cl}_{2}$ and recrystallized from $\mathrm{CH}_{2} \mathrm{Cl}_{2} / n$-hexane solution. Dark-green crystals were obtained. The yield: $1.78 \mathrm{~g}, 72.36 \%$. Calc. For $\mathrm{C}_{40} \mathrm{H}_{32} \mathrm{Cl}_{2}$ $\mathrm{Cr}_{3} \mathrm{~N}_{12}: \mathrm{C}, 52.92 ; \mathrm{H}, 3.55 ; \mathrm{N}, 18.52 \%$. Found $\mathrm{C}, 52.90 ; \mathrm{H}$, $3.58 ; \mathrm{N}, 18.57 \%$. Selected IR $\left(\mathrm{KBr}, \mathrm{cm}^{-1}\right): 1602 \mathrm{~s}, 1563 \mathrm{vs}$, $1467 \mathrm{vs}, 1427 \mathrm{~s}, 1360 \mathrm{~s} ; \mathrm{FAB} / \mathrm{MS} \mathrm{m} / \mathrm{z}: 906.7\left(\left[\mathrm{Cr}_{3}(\mathrm{dpa})_{4}\right.\right.$ $\left.\left.\mathrm{Cl}_{2}\right]^{+}\right), 871.2\left(\left[\mathrm{Cr}_{3}(\mathrm{dpa})_{4} \mathrm{Cl}\right]^{+}\right), 836.2\left(\left[\mathrm{Cr}_{3}(\mathrm{dpa})_{4}\right]^{+}\right)$. $\left[\mathrm{Cr}_{3}(\mathrm{dpa})_{4} \mathrm{Cl}\left(\mathrm{OC}_{2} \mathrm{H}_{5}\right)\right] \mathrm{OH} \cdot 2.5 \mathrm{H}_{2} \mathrm{O} \cdot \mathrm{C}_{2} \mathrm{H}_{5} \mathrm{OC}_{2} \mathrm{H}_{5}(\mathbf{1})$ : a solution of $\mathrm{NaOH}(2.4 \mathrm{mg}, 0.055 \mathrm{mmol})$ in $10 \mathrm{ml} \mathrm{C}_{2} \mathrm{H}_{5} \mathrm{OH}$ was added to a solution of $\mathrm{Cr}_{3}(\mathrm{dpa})_{4} \mathrm{Cl}_{2}(25 \mathrm{mg}, 0.027 \mathrm{mmol})$ in $10 \mathrm{ml} \mathrm{CH}_{3} \mathrm{OH}$. The reaction mixture was stirred for $24 \mathrm{~h}$ in the air at room temperature, while its color changed gradually from dark green to dark brown. After filtrating, the filtrate was condensed to $10 \mathrm{ml}$, and dark brown single crystals were obtained by diethyl ether diffusion after 1 week. The yield: $11.80 \mathrm{mg}(40.31 \%)$. Calc. for $\mathrm{C}_{46} \mathrm{H}_{53}$ $\mathrm{ClCr}_{3} \mathrm{~N}_{12} \mathrm{O}_{5.5}: \mathrm{C}, 52.44 ; \mathrm{H}, 5.07 ; \mathrm{N}, 15.96$. Found: C, 52.17; $\mathrm{H}, 5.08 ; \mathrm{N}, 15.97 \%$. Selected IR $\left(\mathrm{KBr}, \mathrm{cm}^{-1}\right)$ : $1608 \mathrm{vs,}$ $1589 \mathrm{vs}, 1569 \mathrm{vs}, 1467 \mathrm{vs}, 1427 \mathrm{~s}, 1360 \mathrm{~s}, 1313 \mathrm{~s}, 1162 \mathrm{~s}$, $1078 \mathrm{~m}, 1037 \mathrm{w}, 600 \mathrm{w} .\left[\mathrm{Cr}_{3}(\mathrm{dpa})_{4}(\mathrm{OH})_{2}\right] \mathrm{ClO}_{4} \cdot 3 \mathrm{H}_{2} \mathrm{O}(2)$ : a solution of $\mathrm{AgCF}_{3} \mathrm{SO}_{3}(11.56 \mathrm{mg}, 0.045 \mathrm{mmol})$ in $2 \mathrm{ml}$ $\mathrm{CH}_{3} \mathrm{OH}$ was added to a solution of $\mathrm{Cr}_{3}(\mathrm{dpa})_{4} \mathrm{Cl}_{2}(50 \mathrm{mg}$, $0.055 \mathrm{mmol}$ ) in $20 \mathrm{ml} \mathrm{CH} \mathrm{CH}_{3} \mathrm{OH}$. The reaction mixture was stirred for $2 \mathrm{~h}$ in the air at room temperature. After separating the $\mathrm{AgCl}$ precipitate, an aqueous solution $(2 \mathrm{ml})$ containing $\mathrm{NaOH}(6.0 \mathrm{mg}, 0.15 \mathrm{mmol})$ and $\mathrm{NaClO}_{4}$ $(6.73 \mathrm{mg}, 0.055 \mathrm{mmol})$ was added to the filtrate. This solution was stirred for $20 \mathrm{~h}$. Dark brown crystals were obtained by evaporating. The yield: $32.66 \mathrm{mg}$ (57.89\%). Calc. for $\mathrm{C}_{40} \mathrm{H}_{40} \mathrm{ClCr}_{3} \mathrm{~N}_{12} \mathrm{O}_{9}$ : C, 46.90; H, 3.94; N, $16.41 \%$.
Found: C, 46.87; H, 3.98; N, 16.37\%. Selected IR (KBr, $\mathrm{cm}^{-1}$ ): 1610vs, 1588vs, 1546s, 1478vs, 1400s, 1360s, 1298s, 1189s, 1100m. MS (FAB, NBA) 871, $\left[\mathrm{Cr}_{3}(\mathrm{dpa})_{4}\right.$ $\left.(\mathrm{OH})_{2}\right]^{+} ; 803,\left[\mathrm{Cr}_{2}(\mathrm{dpa})_{4} \mathrm{OH}\right]^{+} ; 786,\left[\mathrm{Cr}_{2}(\mathrm{dpa})_{4}\right]^{+} ; 631$, $\left[\mathrm{Cr}_{2}(\mathrm{dpa})_{3} \mathrm{OH}\right]^{+} ; 615,\left[\mathrm{Cr}(\mathrm{dpa})_{4}\right]^{+} ; 462,\left[\mathrm{Cr}_{2}(\mathrm{dpa})_{2} \mathrm{OH}\right]^{+}$; 392, $\left[\mathrm{Cr}(\mathrm{dpa})_{2}\right]^{+}$. $\left[\mathrm{Cr}_{3}(\mathrm{dpa})_{4} \mathrm{~F}_{2} \mathrm{Na}\left(\mathrm{H}_{2} \mathrm{O}\right) \mathrm{BF}_{4}\right] \mathrm{BF}_{4} \cdot \mathrm{CH}_{3} \mathrm{OH}$ (3): a methanol solution (2 ml) of $\mathrm{AgBF}_{4}(21.41 \mathrm{mg}$, $0.110 \mathrm{mmol}$ ) was slowly added to a methanol solution $(20 \mathrm{ml})$ of $\mathrm{Cr}_{3}(\mathrm{dpa})_{4} \mathrm{Cl}_{2}(50 \mathrm{mg}, 0.055 \mathrm{mmol})$ with stirring for $2 \mathrm{~h}$ in the air. After filtration, the reaction mixture, an aqueous solution $(2 \mathrm{ml})$ of $\mathrm{NaOH}(4.8 \mathrm{mg}, 0.12 \mathrm{mmol})$ was added to the filtrate. The single crystals were obtained by slowly evaporating the solution. The yield: $38.59 \mathrm{mg}$ (62.56\%). Calc. for $\mathrm{C}_{41} \mathrm{H}_{38} \mathrm{~B}_{2} \mathrm{Cr}_{3} \mathrm{~F}_{10} \mathrm{~N}_{12} \mathrm{NaO}_{2}$ : C, 43.91; H, 3.42; N, 14.99. Found: C, 43.96; H, 3.38; N, $14.97 \%$. Selected IR $\left(\mathrm{KBr}, \mathrm{cm}^{-1}\right)$ : 1611vs, 1583vs, 1550s, 1486s, 1392s, 1350s, 1287s, 1180s, 1093m.

The infrared spectra were recorded on a Nicolet Fourier Transform IR, MAGNA-IR 500 spectrometer in the range of $500-4000 \mathrm{~cm}^{-1}$ using $\mathrm{KBr}$ disc technique. FAB-MS mass spectra were measured in a JEOL HX-110 HF double focusing spectrometer operating in the positive ion detection mode. Magnetic measurement of complex 1 was carried out on polycrystalline samples with a SQUID magnetometer. Molar magnetic susceptibility was recorded every $2 \mathrm{~K}$ from 4 to $50 \mathrm{~K}$ and every $5 \mathrm{~K}$ in the range of $50-270 \mathrm{~K}$ with $10,000 \mathrm{G}$ external field.

All the X-ray data were collected on a NONIUS Kappa CCD diffractometer installed with monochromatized Mo $\mathrm{K}_{\alpha}$ radiation, $\lambda=0.71073 \AA$. Cell parameters were retrieved and refined using DENZO-SMN software on all observed reflections [12]. Data reduction was performed with DENZO-SMN software [12]. An empirical absorption was based on the symmetry-equivalent reflections and absorption corrections were applied with the SORTAV program [13]. All structures were solved by using the SHELXs-97 [14] and refined with SHELXs-97 [15] by fullmatrix least squares on $F^{2}$ values. Hydrogen atoms were fixed at calculated positions and refined using a riding mode. The crystallographic data of complexes 1-3 are listed in Table 1. Selected bond lengths and angles of 1-3 are listed in Tables $2-4$, respectively.

\section{Results and discussion}

The synthesis of $\mathrm{Cr}_{3}(\mathrm{dpa})_{4} \mathrm{Cl}_{2}$ has been reported by Cotton using lithium salt at $-78^{\circ} \mathrm{C}$ [8]. This method gives easily treated product with high yield. We have developed a naphthalene method to synthesize metal string complexes. It has been applied to the synthesis of long metal string complexes successfully [16-21]. This method can drive water out of the reaction system efficiently because of the high hydrophobic activity of naphthalene and the high reaction temperature. The starting material, $\mathrm{Cr}_{3}(\mathrm{dpa})_{4} \mathrm{Cl}_{2}$, in this work was synthesized by the naphthalene method. 
Table 1

The crystallographic data of the complexes 1-3

\begin{tabular}{|c|c|c|c|}
\hline & 1 & 2 & 3 \\
\hline Empirical formula & $\mathrm{C}_{46} \mathrm{H}_{54} \mathrm{ClCr}_{3} \mathrm{~N}_{12} \mathrm{O}_{5.5}$ & $\mathrm{C}_{40} \mathrm{H}_{40} \mathrm{ClCr}_{3} \mathrm{~N}_{12} \mathrm{O}_{9}$ & $\mathrm{C}_{41} \mathrm{H}_{38} \mathrm{~B}_{2} \mathrm{Cr}_{3} \mathrm{~F}_{10} \mathrm{~N}_{12} \mathrm{NaO}_{2}$ \\
\hline $\operatorname{Mr}\left(\mathrm{g} \mathrm{mol}^{-1}\right)$ & 1053.45 & 1024.29 & 1121.44 \\
\hline Space group & $P 2{ }_{1} / c$ & $\operatorname{Pna2}_{1}$ & $P 2_{1} / n$ \\
\hline$a(\AA)$ & $19.9998(4)$ & $18.3373(2)$ & $12.3902(1)$ \\
\hline$b(\AA)$ & $15.9756(3)$ & $16.8220(2)$ & $16.2081(2)$ \\
\hline$c(\AA)$ & $16.9943(3)$ & $14.0268(2)$ & $23.4119(3)$ \\
\hline$B\left({ }^{\circ}\right)$ & $114.0548(8)$ & 90 & $98.8725(6)$ \\
\hline$V\left(\AA^{3}\right)$ & $4958.28(16)$ & $4326.85(9)$ & $4645.35(9)$ \\
\hline$Z$ & 4 & 4 & 4 \\
\hline Calculated density $\left(\mathrm{g} \mathrm{cm}^{-3}\right)$ & 1.411 & 1.572 & 1.603 \\
\hline$\mu\left(\mathrm{mm}^{-1}\right)$ & 0.758 & 0.872 & 0.790 \\
\hline Number of reflections collected & 8721 & 9696 & 10,658 \\
\hline Restraints/parameters & $12 / 618$ & $1 / 583$ & $/ 0 / 642$ \\
\hline Final $R[I>2 \sigma(I)]$ & $R_{1}=0.0791, w R_{2}=0.1927$ & $R_{1}=0.0683, w R_{2}=0.1804$ & $R_{1}=0.0670, w R_{2}=0.1568$ \\
\hline GOF & 1.099 & 1.077 & 1.055 \\
\hline
\end{tabular}

Complexes 1, 2 and 3 were prepared from $\mathrm{Cr}_{3}(\mathrm{dpa})_{4} \mathrm{Cl}_{2}$ in the air at room temperature. All products have the $\left[\mathrm{Cr}_{3}\right.$ $\left.(\mathrm{dpa})_{4}\right]^{3+}$ core. It indicates that the $\left[\mathrm{Cr}_{3}(\mathrm{dpa})_{4}\right]^{2+}$ core is easily oxidized by oxygen in the air. It is reported that the oxidization reaction may be slow at low temperature $\left(-72{ }^{\circ} \mathrm{C}\right)$ [16]. Until now, no evidence has shown that the trichromium metal string complex $\left(\left[\mathrm{Cr}_{3}(\mathrm{dpa})_{4}\right]^{2+}\right)$ is not stable in the solid state. After successfully introducing water molecules to the axial site of metal string complex [7], we are interested in the hydroxide anion as axial ligand of complexes. Considering that the hydroxide anion is a strong coordinated ligand, it may replace the chloride ions directly. At first, we tried to carry out this replacement without silver salt to remove the axial ligands. However, complex $\mathbf{1}$ has shown that it is difficult to replace the two axial chloride ligands by $\mathrm{OH}^{-}$anions even with stirring for $24 \mathrm{~h}$. The strong $\mathrm{C}_{2} \mathrm{H}_{5} \mathrm{O}^{-}$ligands, which comes from the deprotonated ethanol molecule, replaces one of the axial chloride ligand. Based on the result, the silver salts, $\mathrm{AgCF}_{3} \mathrm{SO}_{3}$, are used to replace the two axial ligands in the metal string complexes at the initial step of self-assembly in the synthesis of complex 2. After many unsuccessful tries, it has been found that $\mathrm{ClO}_{4}^{-}$is important in growing the single crystal of complex $\mathbf{2}$. Complex $\mathbf{3}$ has an interesting structure. Its synthetic conditions are similar to complex $\mathbf{2}$ except for using $\mathrm{AgBF}_{4}$ to replace $\mathrm{AgCF}_{3} \mathrm{SO}_{3}$. The fluoride, which comes from the decomposition of the $\mathrm{BF}_{4}^{-}$anion, replaces the axial $\mathrm{Cl}^{-}$ligand. One of the axial fluoride ions have very short distances with $\mathrm{Na}^{+}$ions and like a bridge ligand to link the $\mathrm{Cr}(\mathrm{II})$ and $\mathrm{Na}^{+}$ions.

\subsection{Crystal structures of complexes 1-3}

\subsubsection{Crystal structures of}

$\left[\mathrm{Cr}_{3}(\mathrm{dpa})_{4} \mathrm{Cl}\left(\mathrm{OC}_{2} \mathrm{H}_{5}\right)\right] \mathrm{OH} \cdot 2.5 \mathrm{H}_{2} \mathrm{O} \cdot \mathrm{C}_{2} \mathrm{H}_{5} \mathrm{OC}_{2} \mathrm{H}_{5} \mathrm{I}$

In all three complexes, $\Sigma \mathrm{Cr}-\mathrm{Cr}$ distances fall in the range of $4.512-4.557 \AA$. That is shorter than those of
$\left[\mathrm{Cr}_{3}(\mathrm{dpa})_{4}\right]^{2+}$ complexes, which are typically in the range of 4.621-4.837 $\AA$ [11]. Although the $\Sigma \mathrm{Cr}-\mathrm{Cr}$ distances are structural evidence for the $\left[\mathrm{Cr}_{3}(\mathrm{dpa})_{4}\right]^{3+}$ core in $\mathbf{1}$, the magnetic susceptibilities of 1 have been measured from 5 to $300 \mathrm{~K}$ to confirm the $\left[\mathrm{Cr}_{3}(\mathrm{dpa})_{4}\right]^{3+}$ core. It is because the counter anion in $\mathbf{1}$ is a hydroxide anion and may sometimes be confused with water molecules in crystallography. $\mu_{\text {eff }}$ value of 1 at room temperature of $4.4 \mu_{\mathrm{B}}$ has been reported for some $\left[\mathrm{Cr}_{3}(\mathrm{dpa})_{4}\right]^{3+}$ complexes [8]. That is slightly higher than the $\mu_{\text {eff }}$ value $\left(3.85 \mu_{\mathrm{B}}\right)$ that has three electrons spin only [9]. It indicated that there is an orbital contribution to $\mu_{\text {eff }}$ value besides the unpaired electron contribution. Complex 1 has a different axial ligand, so, no disorder for the middle $\mathrm{Cr}$ (II) (Fig. 1a). However, the ethyl group of axial ligands $\left(\mathrm{OC}_{2} \mathrm{H}_{5}\right)$ in $\mathbf{1}$ is disorder.

\subsubsection{Crystal structures of $\left[\mathrm{Cr}_{3}(\mathrm{dpa})_{4}(\mathrm{OH})_{2}\right] \mathrm{ClO}_{4} \cdot 3 \mathrm{H}_{2} \mathrm{O} 2$}

Both axial ligands are hydroxide anions in complex 2 (Fig. 1b). The middle $\mathrm{Cr}$ atom is in disorder and splits into two parts with the distance of $\mathrm{Cr} 2-\mathrm{Cr} 2^{\prime}(0.512(2) \AA)$. This often happens when the two axial ligands are the same in

Table 2

Select bond length $(\AA)$ and angle $\left({ }^{\circ}\right)$ for $\mathbf{1}$

\begin{tabular}{|c|c|c|c|}
\hline $\operatorname{Cr}(1)-\operatorname{Cr}(2)$ & $1.9606(13)$ & $\operatorname{Cr}(2)-\operatorname{Cr}(3)$ & $2.6159(13)$ \\
\hline $\mathrm{Cr}(1)-\mathrm{Cl}(1)$ & $2.5042(18)$ & $\mathrm{Cr}(3)-\mathrm{O}(1)$ & $1.881(4)$ \\
\hline $\mathrm{Cr}(1)-\mathrm{N}(1)$ & $2.091(5)$ & $\mathrm{Cr}(1)-\mathrm{N}(7)$ & $2.101(5)$ \\
\hline $\mathrm{Cr}(1)-\mathrm{N}(4)$ & $2.123(5)$ & $\mathrm{Cr}(1)-\mathrm{N}(10)$ & $2.110(6)$ \\
\hline $\mathrm{Cr}(2)-\mathrm{N}(11)$ & $2.003(5)$ & $\mathrm{Cr}(2)-\mathrm{N}(5)$ & $2.017(5)$ \\
\hline $\mathrm{Cr}(2)-\mathrm{N}(2)$ & $1.998(5)$ & $\mathrm{Cr}(2)-\mathrm{N}(8)$ & $2.016(5)$ \\
\hline $\mathrm{Cr}(3)-\mathrm{N}(9)$ & $2.063(5)$ & $\mathrm{Cr}(3)-\mathrm{N}(3)$ & $2.074(5)$ \\
\hline $\mathrm{Cr}(3)-\mathrm{N}(6)$ & $2.096(5)$ & $\mathrm{Cr}(3)-\mathrm{N}(12)$ & $2.078(5)$ \\
\hline $\mathrm{Cr}(1)-\mathrm{Cr}(2)-\mathrm{Cr}(3)$ & $178.89(6)$ & $\mathrm{Cr}(2)-\mathrm{Cr}(1)-\mathrm{Cl}(1)$ & $178.49(7)$ \\
\hline $\mathrm{O}(1)-\mathrm{Cr}(3)-\mathrm{Cr}(2)$ & $178.33(17)$ & $\mathrm{N}(1)-\mathrm{Cr}(1)-\mathrm{N}(4)$ & $177.5(2)$ \\
\hline $\mathrm{Cr}(2)-\mathrm{Cr}(1)-\mathrm{N}(7)$ & $88.90(15)$ & $\mathrm{N}(7)-\mathrm{Cr}(1)-\mathrm{N}(10)$ & $176.5(2)$ \\
\hline $\mathrm{N}(2)-\mathrm{Cr}(2)-\mathrm{N}(5)$ & $166.3(2)$ & $\mathrm{N}(11)-\mathrm{Cr}(2)-\mathrm{N}(8)$ & $164.6(2)$ \\
\hline $\mathrm{Cr}(1)-\mathrm{Cr}(2)-\mathrm{N}(8)$ & $97.85(15)$ & $\mathrm{N}(2)-\mathrm{Cr}(2)-\mathrm{N}(8)$ & $90.0(2)$ \\
\hline $\mathrm{N}(9)-\operatorname{Cr}(3)-\mathrm{N}(12)$ & $169.4(2)$ & $\mathrm{N}(3)-\mathrm{Cr}(3)-\mathrm{N}(6)$ & $168.8(2)$ \\
\hline $\mathrm{N}(9)-\mathrm{Cr}(3)-\mathrm{N}(3)$ & $89.1(2)$ & $\mathrm{N}(9)-\mathrm{Cr}(3)-\mathrm{N}(6)$ & $88.4(2)$ \\
\hline
\end{tabular}


Table 3

Select bond length $(\AA)$ and angle $\left({ }^{\circ}\right)$ for 2

\begin{tabular}{lclr}
\hline $\mathrm{Cr}(1)-\mathrm{Cr}\left(2^{\prime}\right)$ & $2.531(3)$ & $\mathrm{Cr}\left(2^{\prime}\right)-\mathrm{Cr}(2)$ & $0.514(2)$ \\
$\mathrm{Cr}(1)-\mathrm{Cr}(2)$ & $2.018(3)$ & $\mathrm{Cr}(2)-\mathrm{Cr}(3)$ & $2.494(3)$ \\
$\mathrm{Cr}(1)-\mathrm{O}(1)$ & $1.894(3)$ & $\mathrm{Cr}(3)-\mathrm{O}(2)$ & $1.895(4)$ \\
$\mathrm{Cr}(1)-\mathrm{N}(1)$ & $2.075(4)$ & $\mathrm{Cr}(1)-\mathrm{N}(7)$ & $2.086(4)$ \\
$\mathrm{Cr}(1)-\mathrm{N}(4)$ & $2.072(4)$ & $\mathrm{Cr}(1)-\mathrm{N}(10)$ & $2.064(4)$ \\
$\mathrm{Cr}(2)-\mathrm{N}(11)$ & $2.037(5)$ & $\mathrm{Cr}(2)-\mathrm{N}(5)$ & $2.028(5)$ \\
$\mathrm{Cr}(2)-\mathrm{N}(2)$ & $2.037(5)$ & $\mathrm{Cr}(2)-\mathrm{N}(8)$ & $2.046(5)$ \\
$\mathrm{Cr}(3)-\mathrm{N}(9)$ & $2.067(4)$ & $\mathrm{Cr}(3)-\mathrm{N}(3)$ & $2.077(4)$ \\
$\mathrm{Cr}(3)-\mathrm{N}(6)$ & $2.087(4)$ & $\mathrm{Cr}(3)-\mathrm{N}(12)$ & $2.058(4)$ \\
$\mathrm{Cr}(1)-\mathrm{Cr}(2)-\mathrm{Cr}(3)$ & $177.60(17)$ & $\mathrm{Cr}(2)-\mathrm{Cr}(1)-\mathrm{O}(1)$ & $177.68(15)$ \\
$\mathrm{O}(2)-\mathrm{Cr}(3)-\mathrm{Cr}(2)$ & $179.40(14)$ & $\mathrm{N}(1)-\mathrm{Cr}(1)-\mathrm{N}(4)$ & $175.73(17)$ \\
$\mathrm{Cr}(2)-\mathrm{Cr}(1)-\mathrm{N}(7)$ & $86.92(15)$ & $\mathrm{N}(7)-\mathrm{Cr}(1)-\mathrm{N}(10)$ & $176.54(17)$ \\
$\mathrm{N}(2)-\mathrm{Cr}(2)-\mathrm{N}(5)$ & $167.2(2)$ & $\mathrm{N}(11)-\mathrm{Cr}(2)-\mathrm{N}(8)$ & $165.1(2)$ \\
$\mathrm{Cr}(1)-\mathrm{Cr}(2)-\mathrm{N}(8)$ & $99.64(18)$ & $\mathrm{N}(2)-\mathrm{Cr}(2)-\mathrm{N}(8)$ & $87.0(2)$ \\
$\mathrm{N}(9)-\mathrm{Cr}(3)-\mathrm{N}(12)$ & $177.21(17)$ & $\mathrm{N}(3)-\mathrm{Cr}(3)-\mathrm{N}(6)$ & $176.42(18)$ \\
$\mathrm{N}(9)-\mathrm{Cr}(3)-\mathrm{N}(3)$ & $90.59(16)$ & $\mathrm{N}(9)-\mathrm{Cr}(3)-\mathrm{N}(6)$ & $88.96(16)$ \\
\hline
\end{tabular}

the $\mathrm{Cr}_{3}(\mathrm{dpa})_{4}^{3+}$ core [8]. So, the bond distances of $\mathrm{Cr}(1)-\mathrm{O}$, $\mathrm{Cr}(1)-\mathrm{N}, \mathrm{Cr}(3)-\mathrm{O}$ and $\mathrm{Cr}(3)-\mathrm{N}$ are the average values of the $\mathrm{Cr}(\mathrm{II})-\mathrm{O}, \mathrm{Cr}(\mathrm{II})-\mathrm{N}, \mathrm{Cr}(\mathrm{III})-\mathrm{O}$ and $\mathrm{Cr}(\mathrm{III})-\mathrm{N}$ bond lengths (Table 3). It should be pointed out that after removing an electron from the $\left[\mathrm{Cr}_{3}(\mathrm{dpa})_{4}\right]^{2+}$ core, the electronic density of a molecule is normally localized in the $\left[\mathrm{Cr}_{3}(\mathrm{dpa})_{4}\right]^{3+}$ core since the two $\mathrm{Cr}(\mathrm{II})$ atoms are bonded quadruply [22]. However, the middle $\mathrm{Cr}(\mathrm{II})$ atom in $\left[\mathrm{Cr}_{3}(\mathrm{dpa})_{4}\right]^{3+}$ core of some $\left[\mathrm{Cr}_{3}(\mathrm{dpa})_{4}\right]^{3+}$ complexes is disorder in crystallography and it makes the bond distances of $\mathrm{Cr}$ (II) and $\mathrm{Cr}$ (III) take their average distances with oxygen and nitrogen.

\subsection{3. $\left[\mathrm{Cr}_{3}(\mathrm{dpa})_{4} \mathrm{~F}_{2} \mathrm{Na}\left(\mathrm{H}_{2} \mathrm{O}\right) \mathrm{BF}_{4}\right] \mathrm{BF}_{4} \cdot \mathrm{CH}_{3} \mathrm{OH} 3$}

The structure reveals that the sodium ion is located in the $\mathrm{Cr}_{3}$ axis with a bond angle of $\mathrm{Cr}(1)-\mathrm{F}(1)-\mathrm{Na}$ in $169.90(13)^{\circ}$ (Fig. 1c). The distance between the $\mathrm{Na}$ and $\mathrm{F}(1)$ is 2.175(3) $\AA$. Two $\mathrm{BF}_{4}^{-}$anions and a water molecule are surrounded with sodium ion (Table 4) with the geometry

Table 4

Select bond length $(\AA)$ and angle $\left({ }^{\circ}\right)$ for $\mathbf{3}$

\begin{tabular}{lclc}
\hline $\mathrm{Cr}(1)-\mathrm{Cr}(2)$ & $1.9771(8)$ & $\mathrm{Cr}(2)-\mathrm{Cr}(3)$ & $2.5384(8)$ \\
$\mathrm{Cr}(1)-\mathrm{F}(1)$ & $1.979(2)$ & $\mathrm{Cr}(3)-\mathrm{F}(2)$ & $1.843(2)$ \\
$\mathrm{Cr}(1)-\mathrm{N}(1)$ & $2.084(3)$ & $\mathrm{Cr}(1)-\mathrm{N}(7)$ & $2.089(3)$ \\
$\mathrm{Cr}(1)-\mathrm{N}(4)$ & $2.078(3)$ & $\mathrm{Cr}(1)-\mathrm{N}(10)$ & $2.067(3)$ \\
$\mathrm{Cr}(2)-\mathrm{N}(11)$ & $2.017(3)$ & $\mathrm{Cr}(2)-\mathrm{N}(5)$ & $2.019(3)$ \\
$\mathrm{Cr}(2)-\mathrm{N}(2)$ & $2.031(3)$ & $\mathrm{Cr}(2)-\mathrm{N}(8)$ & $2.018(3)$ \\
$\mathrm{Cr}(3)-\mathrm{N}(9)$ & $2.063(3)$ & $\mathrm{Cr}(3)-\mathrm{N}(3)$ & $2.065(3)$ \\
$\mathrm{Cr}(3)-\mathrm{N}(6)$ & $2.046(3)$ & $\mathrm{Cr}(3)-\mathrm{N}(12)$ & $2.055(3)$ \\
$\mathrm{Na}-\mathrm{F}(1)$ & $2.175(3)$ & $\mathrm{Na}-\mathrm{F}(3)$ & $2.187(3)$ \\
$\mathrm{Na}-\mathrm{O}(1)$ & $2.248(5)$ & $\mathrm{Na}-\mathrm{F}(8) \# 1$ & $2.395(4)$ \\
$\mathrm{Na}-\mathrm{F}(10) \# 1$ & $2.523(4)$ & & \\
$\mathrm{Cr}(1)-\mathrm{Cr}(2)-\mathrm{Cr}(3)$ & $178.24(4)$ & $\mathrm{Cr}(2)-\mathrm{Cr}(1)-\mathrm{F}(1)$ & $179.17(8)$ \\
$\mathrm{F}(2)-\mathrm{Cr}(3)-\mathrm{Cr}(2)$ & $177.75(8)$ & $\mathrm{F}(1)-\mathrm{Na}-\mathrm{O}(1)$ & $113.68(17)$ \\
$\mathrm{F}(3)-\mathrm{Na}-\mathrm{O}(1)$ & $107.66(19)$ & $\mathrm{F}(1)-\mathrm{Na}-\mathrm{F}(3)$ & $100.71(14)$ \\
$\mathrm{Cr}(1)-\mathrm{F}(1)-\mathrm{Na}$ & $169.90(13)$ & $\mathrm{B}(1)-\mathrm{F}(3)-\mathrm{Na}$ & $128.6(3)$ \\
$\mathrm{N}(1)-\mathrm{Cr}(1)-\mathrm{N}(4)$ & $176.89(13)$ & $\mathrm{F}(1)-\mathrm{Cr}(1)-\mathrm{N}(10)$ & $89.64(11)$ \\
$\mathrm{N}(10)-\mathrm{Cr}(1)-\mathrm{N}(1)$ & $88.39(13)$ & $\mathrm{N}(7)-\mathrm{Cr}(1)-\mathrm{N}(4)$ & $91.81(13)$ \\
\hline
\end{tabular}

$\# 1 a-x+5 / 2, y+1 / 2,-z+1 / 2$.
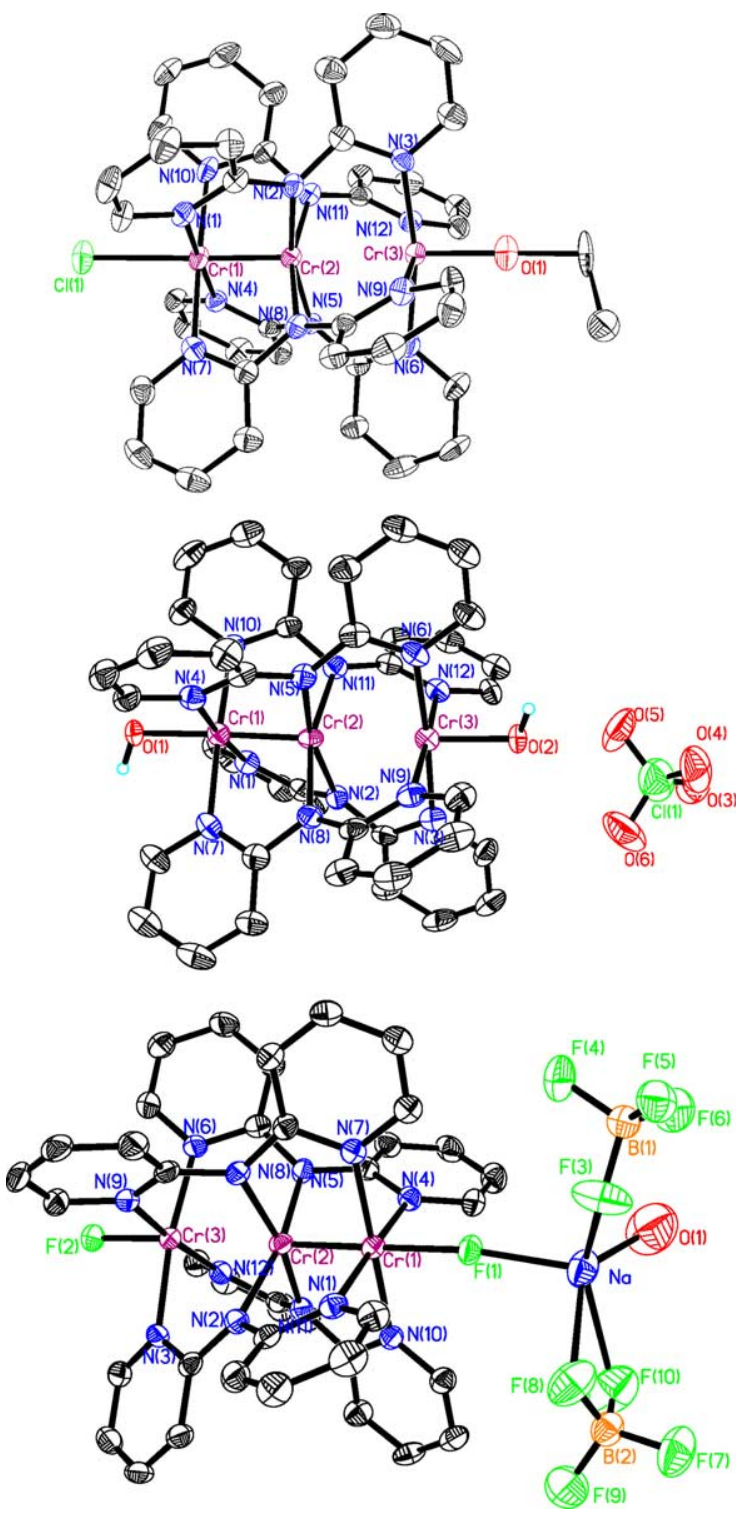

Fig. 1. ORTEP drawing of the molecular structures of complexes $\mathbf{1}, \mathbf{2}$ and $\mathbf{3}$ (50\% thermal ellipsoids).

considered as a distorted trigonal [23] with extra long $\mathrm{Na}-\mathrm{F}(10)(2.523 \AA)$. The average distances of $\mathrm{Na}-\mathrm{F}$ and $\mathrm{Na}-\mathrm{O}$ bonds are shorter than those reported in the literature [24,25]. No molecular disorder with the middle $\mathrm{Cr}$ (II) splitting into two parts has been found in $\mathbf{3}$. Obviously, the bridge of $F(1)$ makes the two fluoride ions coordinated to the metal string complex asymmetrically.

\subsection{Molecular packing in the solid states of the complexes $\mathbf{1 - 3}$}

The three complexes can be considered as mini-1D asymmetrically chains since the distance between the two axial ligands is around $1 \mathrm{~nm}$. The four all-syn type dpa ${ }^{-}$ ligands have wrapped around the mini 1D chain, in which all pyridine rings can act as the hydrogen bonding functional 
groups as do the axial ligands. The types of hydrogen bonding in three supramolecular systems are $\mathrm{C}-\mathrm{H} \cdots \mathrm{O}$, $\mathrm{C}-\mathrm{H} \cdots \mathrm{Cl}, \mathrm{C}-\mathrm{H} \cdots \mathrm{F}$ and $\mathrm{O}-\mathrm{H} \cdots \mathrm{O}$. The first three type of hydrogen bonding is weaker and non-conventional hydrogen bonding. Recently, it has been found that these less known and weaker hydrogen bonding can contribute to crystal stability [26-29]. In solid state packing systems of complexes 1-3, all the carbon atoms in the $\mathrm{C}-\mathrm{H} \cdots \mathrm{O}$ (or $\mathrm{Cl}$, $\mathrm{F})$ are in the aromatic rings. So, these electronic rich carbon atoms can enhance the interaction with $\mathrm{O}$ (or $\mathrm{Cl}, \mathrm{F}$ ) atoms. On the other hand, the van der Waals interactions also play the important role in the solid state packing of the three complexes cooperatively.

\subsection{1. $\left[\mathrm{Cr}_{3}(\mathrm{dpa})_{4} \mathrm{Cl}\left(\mathrm{OC}_{2} \mathrm{H}_{5}\right)\right] \mathrm{OH} \cdot 2.5 \mathrm{H}_{2} \mathrm{O} \cdot \mathrm{C}_{2} \mathrm{H}_{5} \mathrm{OC}_{2} \mathrm{H}_{5} \mathrm{I}$}

In $\mathbf{1}$, one of the axial ligands, $\mathrm{Cl}^{-}$, forms intermolecular hydrogen bonding with $\mathrm{C}(2 \mathrm{~A})-\mathrm{H}(2 \mathrm{AA})[\mathrm{H}(2 \mathrm{AA}) \cdots \mathrm{Cl}(1)$ : $2.68 \AA, \mathrm{C}(2 \mathrm{~A})-\mathrm{H}(2 \mathrm{AA}) \cdots \mathrm{Cl}(1): \quad 162.0^{\circ}, \mathrm{C}(2 \mathrm{~A}) \cdots \mathrm{Cl}(1)$ :
$3.51 \AA$ A which links the metal string species to the 1D chain. These are the typical values of this kind H-bond [30]. The adjacent molecules are nearly all head-to-head types (Fig. 2a). Therefore, this 1D polymer has a double-chain structure. All the $\mathrm{Cl}^{-}$terminals are toward the inside of the double chain. The other axial ligand, $\mathrm{C}_{2} \mathrm{H}_{5} \mathrm{O}^{-}$, is toward the outside of the chain and acts as hydrogen donor to form hydrogen bonding in two directions. In the $2 \mathrm{D}$ layer, the solvent water molecules have hydrogen bonding with an axial ligand $\mathrm{C}_{2} \mathrm{H}_{5} \mathrm{O}^{-}[\mathrm{O}(4) \cdots \mathrm{H}(41 \mathrm{~B}): 2.46 \AA$, $\mathrm{C}(41)-$ $\mathrm{H}(41 \mathrm{~B}) \cdots \mathrm{O}(4): 169.6^{\circ}, \mathrm{C}(41) \cdots \mathrm{O}(4): 3.44 \AA$; $\mathrm{O}(5) \cdots$ $\mathrm{H}(41 \mathrm{H}): \quad 2.12 \AA, \quad \mathrm{C}(41 \mathrm{~A})-\mathrm{H}(41 \mathrm{H}) \cdots \mathrm{O}(5): \quad 161.4^{\circ}$, $\mathrm{C}(41 \mathrm{~A}) \cdots \mathrm{O}(5): 3.07 \AA]$ and $\mathrm{C}_{2} \mathrm{H}_{5} \mathrm{OC}_{2} \mathrm{H}_{5}[\mathrm{O}(2) \cdots \mathrm{H}(22 \mathrm{~B})$ : $2.51 \AA, C(22 \mathrm{~A})-\mathrm{H}(22 \mathrm{~B}) \cdots \mathrm{O}(2): 151.0^{\circ}, \mathrm{C}(22 \mathrm{~A}) \cdots \mathrm{O}(2)$ : $3.38 \AA$ ] (Fig. 2b). These distances of $\mathrm{O} \cdots \mathrm{H}$ are shorter than those in the dimethyl ether dimer systems (2.52$2.59 \AA$ A). Judging from this, the hydroxide anion $[\mathrm{O}(6)]$ has a van der Waals interaction with the water molecules between

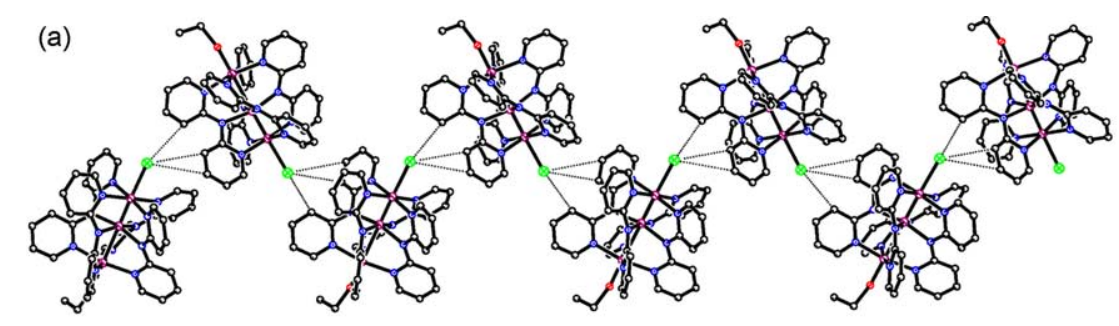

(b)
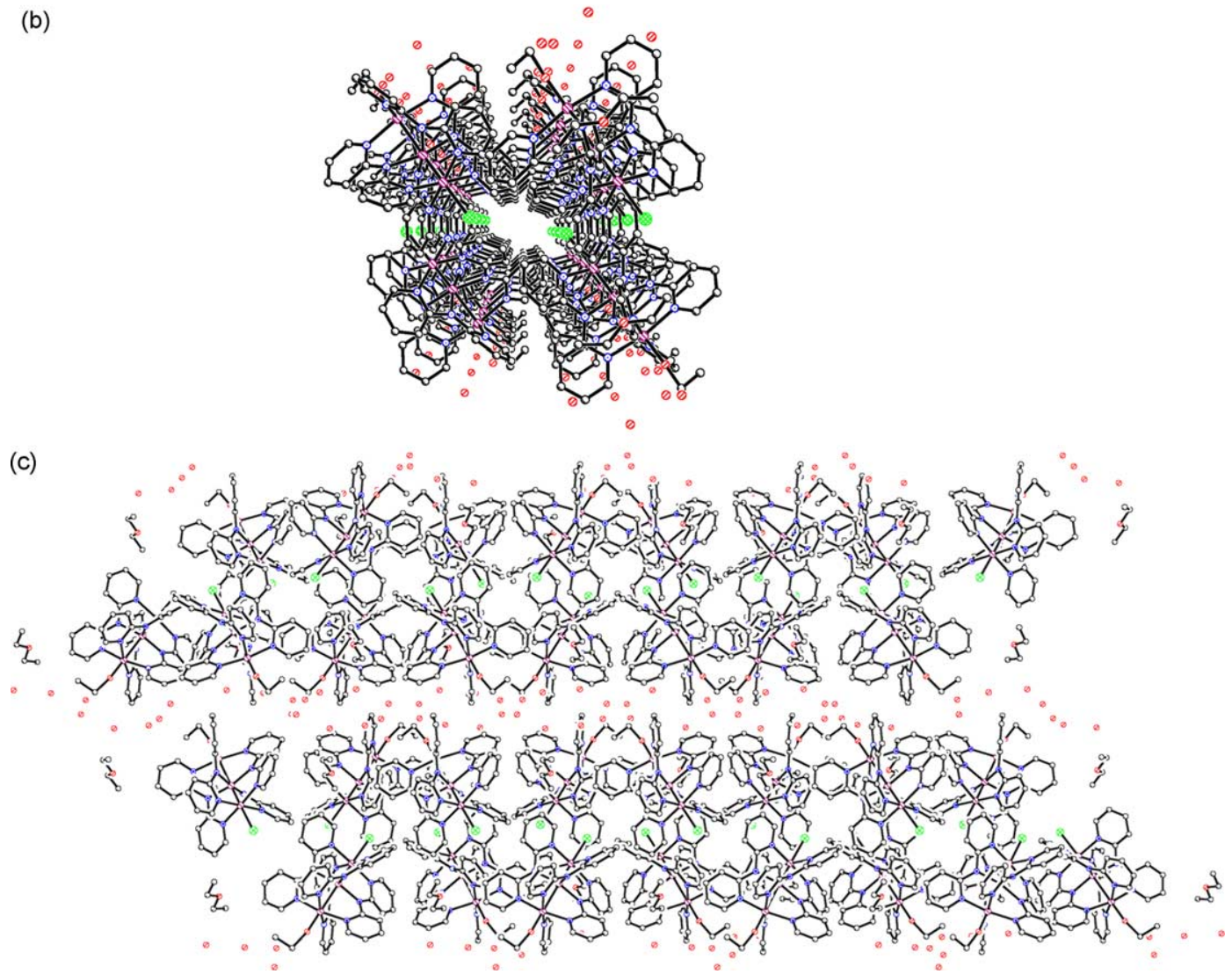

Fig. 2. Molecular packing of complex 1 in crystal lattice: (a) one-dimensional chain structure; (b) 2D; 3D structure view down from $c$ axis. 
the adjacent layers $[\mathrm{O}(5 \mathrm{AB}) \cdots \mathrm{O}(6 \mathrm{E}): 3.065 \AA$ ] instead of H-bond, which links the 2D layers to a three-dimensional packing (Fig. 2c). 1 is a rare example of novel sandwich structure.

\subsection{2. $\left[\mathrm{Cr}_{3}(\mathrm{dpa})_{4}(\mathrm{OH})_{2}\right] \mathrm{ClO}_{4} \cdot 3 \mathrm{H}_{2} \mathrm{O} 2$}

The oxygen atoms of two hydroxide ligands in axial positions in $\mathbf{2}$ have van der Waals interactions with solvent water molecules. The details are $\mathrm{H}(1) \cdots \mathrm{O}(9): 2.48 \AA$, $\mathrm{O}(1) \cdots \mathrm{O}(9): 2.92 \AA ; \mathrm{H}(7) \cdots \mathrm{O}(2): 2.30 \AA, \mathrm{O}(2) \cdots \mathrm{O}(7)$ : $2.81 \AA$. They are not considered as H-bond because the angles of $\mathrm{O}(1)-\mathrm{H}(1) \cdots \mathrm{O}(9)$ and $\mathrm{O}(7)-\mathrm{H}(7) \cdots \mathrm{O}(2)$ are 113.1 and $122.6^{\circ}$, respectively, which are far from the linearity. One of the hydroxide axial ligands acts as the hydrogen acceptor, and the other acts as hydrogen donor. Obviously, the hydroxide anion is better as a hydrogen acceptor than the hydrogen donor since the hydrogen bonding interaction of $\mathrm{O}(2) \cdots \mathrm{O}(7)$ is stronger than that of $\mathrm{O}(1) \cdots \mathrm{O}(9)$. It shows that the hydroxide group has high electron density that makes it prefer to accept the proton. In $\mathbf{2}$, the hydroxide axial ligand cannot assemble the 1D chain directly since it is too small in volume as compared with the $\left[\mathrm{Cr}_{3}(\mathrm{dpa})_{4}\right]^{3+}$ core. Compared with $\left[\mathrm{Ni}_{3}(\mathrm{dpa})_{4}\left(\mathrm{H}_{2} \mathrm{O}\right)_{2}\right]\left[\mathrm{Ni}_{3}(\mathrm{dpa})_{4} \mathrm{~F}_{2}\right]$ $\left(\mathrm{BF}_{4}\right)_{2} \cdot 2 \mathrm{CH}_{3} \mathrm{OH}$ [7], the water molecule and hydroxide group, as axial ligands, are quite different in self-assembly of metal string complexes. The $\mathrm{ClO}_{4}^{-}$anion has formed $\mathrm{H}$-bond with hydrogen atoms of the pyridine rings and solvent molecules $[\mathrm{O}(4) \cdots \mathrm{H}(1 \mathrm{AA}): 2.42 \AA$, $\mathrm{C}(1 \mathrm{~A})-\mathrm{H}(1 \mathrm{AA}) \cdots \mathrm{O}(4): 137.4^{\circ}, \mathrm{C}(1 \mathrm{~A}) \cdots \mathrm{O}(4): 3.18 \AA$; $\mathrm{H}(37 \mathrm{~B}) \cdots \mathrm{O}(5): 2.58 \AA, \mathrm{C}(37 \mathrm{~A})-\mathrm{H}(37 \mathrm{~B}) \cdots \mathrm{O}(5): 131.9^{\circ}$, $\mathrm{O}(5) \cdots \mathrm{C}(37 \mathrm{~A}): 3.29 \AA$ ] (Fig. 3a). Although the bond angles are small but they are still in the rational range [6]. So, they should be very weak H-bonds. This introduces the formation of double chain again similar with $\mathbf{1}$. Different from $\mathbf{1}$, the axis of the mini-1D chain in $\mathbf{2}$ is almost parallel in the double-chain structure. These double chains are also linked by van der Waals interactions with solve water molecules [O(8C) $\cdots \mathrm{C}(13): 3.372 \AA]$ (Fig. 3b) in 2D and 3D directions. The adjacent layers are packed in a shift of distance $(4.205 \AA)$ along the $b$ axis regularly. There is a onedimensional channel along $a$ axis in which the $\mathrm{ClO}_{4}^{-}$anions and water molecules are inserted. The diameter of

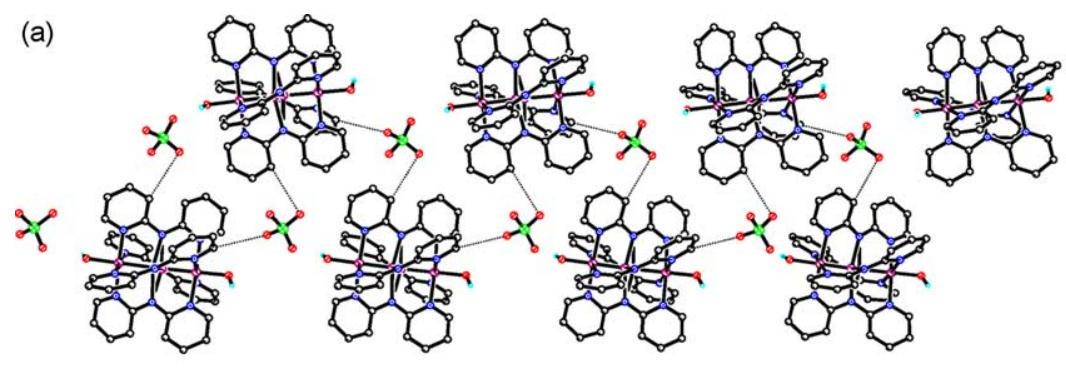

(b)

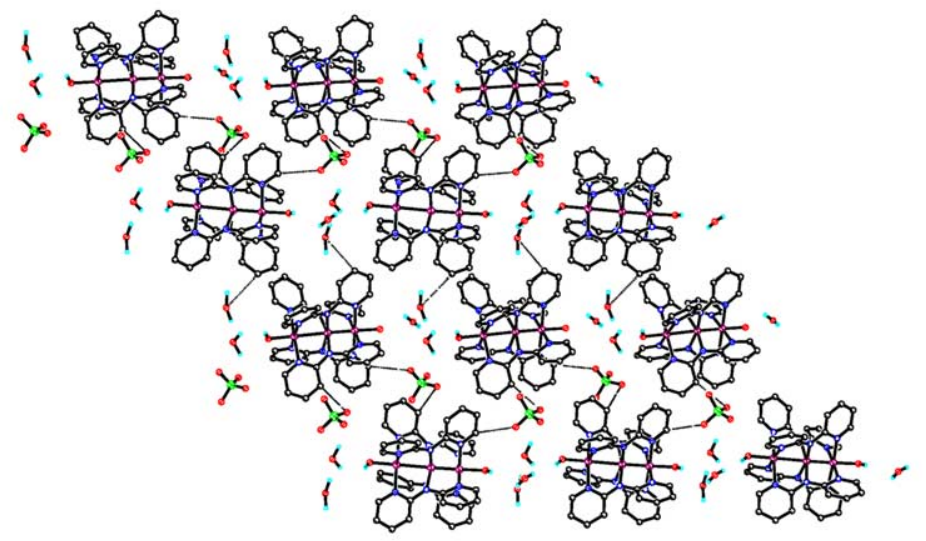

(c)

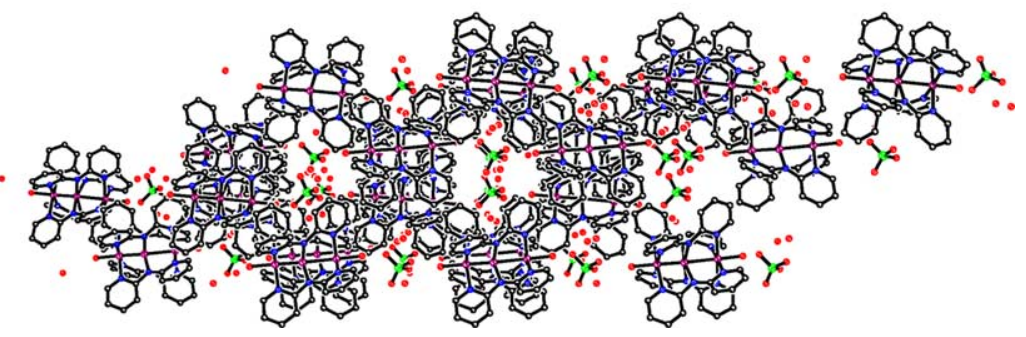

Fig. 3. Molecular packing of complex 2 in crystal lattice: (a) one-dimensional chain structure; 2D (b) and 3D (c) structure view down from $a$ axis. 


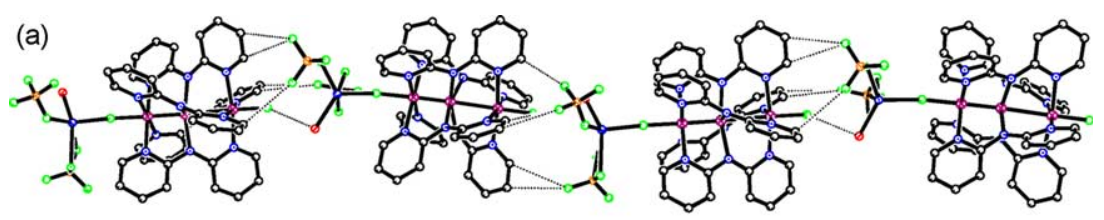

(b)
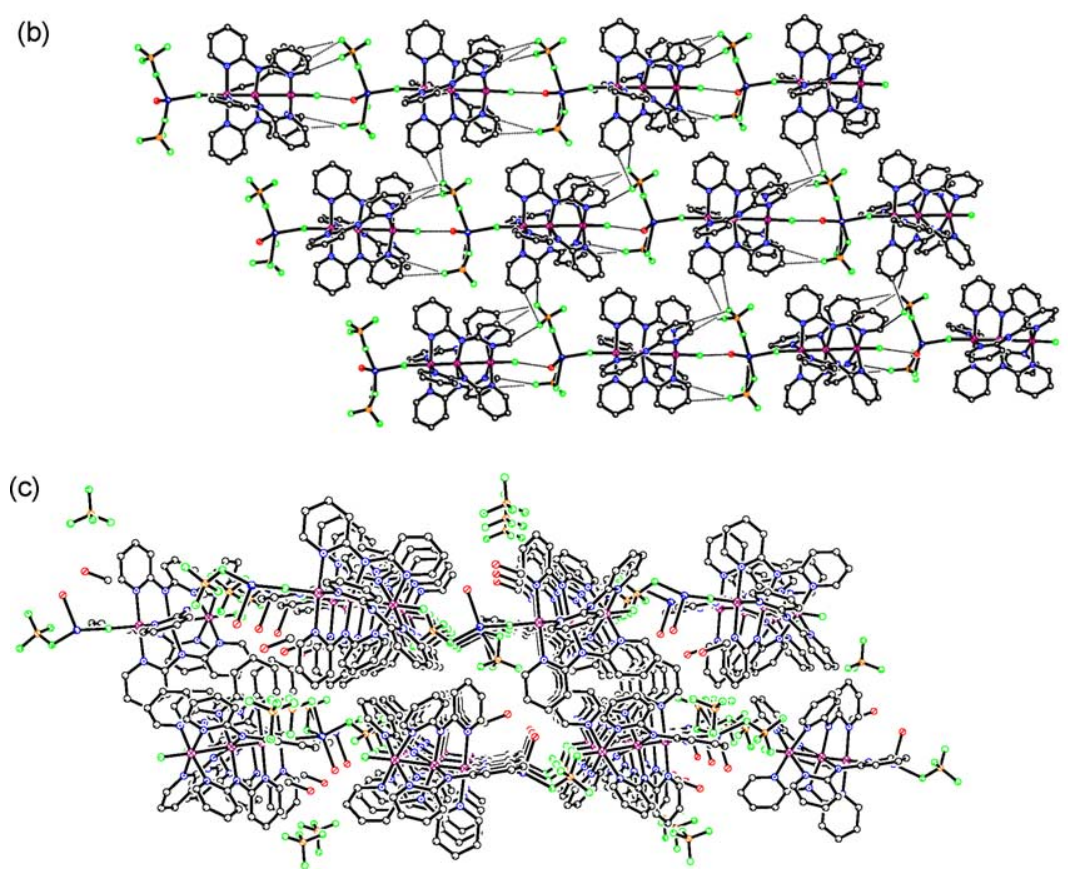

Fig. 4. Molecular packing of complex $\mathbf{3}$ in crystal lattice: (a) one-dimensional chain structure; (b) 2D layer structure view down from $b$ axis; (c) 3D structure view down from a axis.

the channel is about $8 \AA$ (Fig. 3c). Thus, the main interaction in solid state of $\mathbf{2}$ is van der Waals interaction only a very weak $\mathrm{H}$-bond along the $1 \mathrm{D}$ double chain.

\subsection{3. $\left[\mathrm{Cr}_{3}(\mathrm{dpa})_{4} \mathrm{~F}_{2} \mathrm{Na}\left(\mathrm{H}_{2} \mathrm{O}\right) \mathrm{BF}_{4}\right] \mathrm{BF}_{4} \cdot \mathrm{CH}_{3} \mathrm{OH} 3$}

One of the free axial ligand, $F(2)$, has van der Waals interaction with a water molecule which coordinates to the $\mathrm{Na}^{+}$ion of the neighbouring metal string molecule $\left[\mathrm{F}(2) \cdots \mathrm{O}(1), 2.87 \AA\right.$ ] (Fig. 4a). The $\mathrm{Cr}_{3} \mathrm{Na}$ axes of the adjacent molecules are not in a line. The angle between them is $160.68^{\circ}$. The torsion angle of the adjacent molecules is $125.18^{\circ}$. The $\mathrm{BF}_{4}^{-}$coordinated to the $\mathrm{Na}^{+}$ion in 3 is a species in constructing $2 \mathrm{D}$ and $3 \mathrm{D}$ hydrogen bonding networks although this type hydrogen bonding is very weak. $\mathrm{F}(4)$ forms $\mathrm{H}$-bond with the hydrogen atom of a pyridine ring $[\mathrm{F}(4) \cdots \mathrm{H}(34 \mathrm{E}): 2.479 \AA, \quad \mathrm{C}(34 \mathrm{D})-\mathrm{H}(34 \mathrm{E}) \cdots \mathrm{F}(4)$ : $\left.154.5^{\circ}, \mathrm{C}(34 \mathrm{D}) \cdots \mathrm{F}(4): 3.362 \AA\right]$ and link the chains to the 2D layer structure (Fig. 4b). The detail of the H-bond in the three-dimensional direction is $\mathrm{F}(7) \cdots \mathrm{H}(18 \mathrm{C}): 2.529 \AA$, $\mathrm{C}(18 \mathrm{~B})-\mathrm{H}(18 \mathrm{C}) \cdots \mathrm{F}(7): 140.9^{\circ}, \mathrm{C}(18 \mathrm{~B}) \cdots \mathrm{F}(7): 3.404 \AA$ (Fig. 4c). These kinds of very weak hydrogen-bonding have been reported in some literature [31-33].

The synthesis and crystal structures of three kinds of trichromium metal string complexes have been studied in this work. The weak intermolecular interactions in the three complexes are H-bond and van der Waals interaction.
The axial ligands and anions of the metal string complexes are key factors to determine the molecular packing of metal string complexes.

Supporting information and structure details. Crystallographic data (excluding structure factors) for the structure(s) reported in this paper have been deposited with the Cambridge Crystallographic Data Centre as supplementary publication numbers: CCDC_209811 (1), CCDC_209812 (2) and CCDC_209813 (3). Copies of the data can be obtained free of charge on application to CCDC, 12, Union Road, Cambridge CB2 1EZ, UK (fax: +44-1223-336-033; E-mail: deposit@ccdc.cam.ac.uk).

\section{Acknowledgements}

We thank the National Science Council, the Ministry of Education of the Republic of China and Beijing Institute of Technology, the People Republic of China for support of this research.

\section{Appendix. Supplementary Material}

Supplementary data associated with this article can be found, in the online version, at doi:10.1016/j.molstruc.2004.07.037 


\section{References}

[1] J.-M. Lehn, Angew. Chem. Int. Ed. Engl. 27 (1988) 89.

[2] J.-M. Lehn, Angew. Chem. Int. Ed. Engl. 29 (1990) 1304.

[3] P. Hobza, J. Sponer, Chem. Res. 99 (1999) 3247.

[4] J.A. Jeffrey, Introduction to Hydrogen Bonding, University Press, Oxford, 1997.

[5] P. Hobza, Z. Havals, Chem. Res. 100 (2000) 4253.

[6] Y. Tatamitan, B. Liu, J. Shimada, T. Ogata, P. Ottavian, A. Maris, W. Caminati, J.L. Alonso, J. Am. Chem. Soc. 124 (2002) 2739.

[7] H. Li, G.-H. Lee, S.-M. Peng, Inorg. Chem. Commun. 1 (2003) 1.

[8] F.A. Cotton, L.M. Daniels, C.A. Murillo, I. Pascual, J. Am. Chem. Soc. 119 (1997) 10223.

[9] R. Clerac, F.A. Cotton, L.M. Daniels, K.R. Dunbar, C.A. Murillo, I. Pascual, Inorg. Chem. 39 (2000) 752.

[10] R. Clerac, F.A. Cotton, L.M. Daniels, C.A. Murillo, H.C. Zhou, Inorg. Chem. 39 (2000) 3414.

[11] F.A. Cotton, L.M. Daniels, C.A. Murillo, X. Wang, Chem. Commun. $1998 ; 39$.

[12] Z. Otwinowski, W. Minor, Processing of X-ray diffraction data collected in oscillation mode in: C.W. Carter, R.M. Sweet Jr. (Eds.),, Methods in Enzymology vol. 276, Academic Press, London, 1997.

[13] R.H. Blessing, Acta Crystallogr. A A51 (1995) 33.

[14] G.M. Sheldrick, Acta Crystallogr. A A46 (1990) 467.

[15] G.M. Sheldrick, SHELXL-97, Program for the Refinement of Crystal Structures, University of Göttingen, Germany, 1997.

[16] S.J. Shieh, C.C. Chou, G.-H. Lee, C.C. Wang, S.M. Peng, Angew. Chem. Int. Ed. Engl. 36 (1997) 56.
[17] C.C. Wang, W.C. Lo, C.C. Chou, G.-H. Lee, J.M. Chen, S.M. Peng, Inorg. Chem. 37 (1998) 4059.

[18] H.C. Chang, J.T. Li, J.T. Lin, C.C. Wang, H.C. Lee, G.-H. Lee, S.M. Peng, Eur. J. Inorg. Chem. 1999; 1243.

[19] S.Y. Lai, T.W. Lin, Y.H. Chen, C.C. Wang, G.-H. Lee, M.H. Yang, M.K. Leung, S.M. Peng, J. Am. Chem. Soc. 121 (1999) 250.

[20] H.C. Chen, C.C. Lee, C.C. Wang, G.-H. Lee, S.Y. Lai, F.Y. Li, C.Y. Mou, S.M. Peng, Chem. Commun. 1999; 1667.

[21] S.M. Peng, C.C. Wang, Y.L. Jang, Y.H.F.Y. Chen, C.Y. Mou, M.K. Leung, J. Magn. Magn. Mater. 209 (2000) 80.

[22] J.F. Berry, F.A. Cotton, L.M. Daniels, C.A. Murillo, X. Wang, Inorg. Chem. 42 (2003) 2418.

[23] E.F. Paulus, M. Kurz, H. Matter, L. Vertesy, J. Am. Chem. Soc. 120 (1998) 8209.

[24] F. Weller, H. Borgholte, H. Stenger, S. Vogler, K. Dehnicke, Z. Naturforsch. B: Chem. Sci. 44 (1989) 12, see also page 1524.

[25] S. Vogler, K. Dehnicke, D. Febske, Z. Naturforsch. B: Chem. Sci. 44 (1989) 11 see alos page 1393.

[26] D. Wiechert, D. Mootz, T. Dahlems, J. Am. Chem. Soc. 119 (1997) 12665.

[27] D. Mootz, A. Deeg, J. Am. Chem. Soc. 114 (1992) 5887.

[28] C. Boskovic, E.K. Brechin, W.E. Streib, K. Folting, J.C. Bollinger, D.N. Hendrickson, G. Christou, J. Am. Chem. Soc. 124 (2002) 3725.

[29] G.R. Desiraju, Angew. Chem. Int. Ed. Engl. 34 (1995) 2311.

[30] C. Boskovic, E.K. Brechin, W.E. Streib, K. Folting, J.C. Bollinger, D.N. Hendrickson, G. Christou, J. Am. Chem. Soc. 124 (2002) 3725.

[31] D. Wiechert, D. Mootz, T. Dahlems, J. Am. Chem. Soc. 119 (1997) 12665.

[32] D. Mootz, A. Deeg, J. Am. Chem. Soc. 114 (1992) 5887.

[33] K.M. Dethlefs, P. Hobza, Chem. Rev. 100 (2000) 143. 